:::: Helmholtz-Zentrum

$\because:$ Geesthacht

Zentrum für Material- und Küstenforschung

\title{
Original
}

Wang, H.; Feng, Y.; Yang, J.; Guo, J.; Zhang, W.:

Targeting REDV peptide functionalized polycationic gene carrier for enhancing the transfection and migration capability of human endothelial cells

In: Journal of Materials Chemistry B (2015) Royal Society of Chemistry

DOI: $10.1039 / c 4 t b 02019 g$ 
Cite this: J. Mater. Chem. B, 2015, 3, 3379

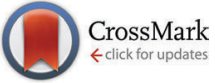

\section{Targeting REDV peptide functionalized polycationic gene carrier for enhancing the transfection and migration capability of human endothelial cells $\dagger$}

\begin{abstract}
Haixia Wang, ${ }^{\text {ab }}$ Yakai Feng, ${ }^{* a b c d}$ Jing Yang, ${ }^{\text {ab }}$ Jintang Guo*a and Wencheng Zhang ${ }^{*}$
Targeting gene engineering should be considered as an effective method for promoting endothelialization of vascular grafts. Herein, we developed a targeting REDV peptide functionalized polycationic gene carrier for carrying the pEGFP-ZNF580 plasmid with the aim of enhancing the transfection and migration capability of human endothelial cells. This polycationic gene carrier with the REDV peptide (mPEG-P(LACO-CL)-PEI-REDV) was prepared by the conjugation of the Cys-Arg-Glu-Asp-Val-Trp (CREDVW) peptide with the amphiphilic block copolymer methoxy poly(ethylene glycol) ether-poly(L-lactide-co- $\varepsilon^{-}$ caprolactone)-poly(ethyleneimine) (mPEG-P(LA-co-CL)-PEI). mPEG-P(LA-CO-CL)-PEI nanoparticles (NP) and $\mathrm{mPEG}-\mathrm{P}(\mathrm{LA}-\mathrm{CO}-\mathrm{CL}$ )-PEI-REDV nanoparticles (REDV-NP) were formed by the self-assembly of the corresponding polycationic polymers, and then their pEGFP-ZNF580 complexes were prepared via the electrostatic interaction with pEGFP-ZNF580 plasmids, respectively. Gel electrophoresis results show that the targeted REDV-NPs could compress pEGFP-ZNF580 plasmids into stable complexes and protect the plasmids against desoxyribonuclease degradation. MTT assay indicates that these targeted REDV-NP/ pEGFP-ZNF580 complexes exhibit better cyto-compatibility than the non-targeted NP/pEGFP-ZNF580 complexes and the control PEI $1800 \mathrm{Da} / \mathrm{pEGFP-ZNF580} \mathrm{complexes.} \mathrm{In} \mathrm{vitro} \mathrm{transfection} \mathrm{experiments} \mathrm{and}$ western blot analysis of EA.hy926 endothelial cells show that the pEGFP-ZNF580 plasmid expression and the relative protein level transfected by targeted REDV-NP/pEGFP-ZNF580 complexes are roughly consistent with that transfected by PEI $25 \mathrm{kDa} / \mathrm{pEGFP}-Z N F 580$ complexes. More importantly, the scratch wound assay results demonstrate that the migration capability of EA.hy 926 cells has been improved significantly by the expression of the pEGFP-ZNF580 plasmid. Our results indicate that the polycationic polymer with functional REDV peptides can be a potential candidate as a pEGFP-ZNF580 plasmid delivery carrier and may be used in the endothelialization of vascular grafts.
\end{abstract}

Received 9th December 2014, Accepted 12th March 2015

DOI: $10.1039 / c 4 t b 02019 \mathrm{~g}$

www.rsc.org/MaterialsB

\section{Introduction}

Small caliber artificial vascular grafts have been widely used in the intervention therapy of cardiovascular and cerebrovascular diseases, ${ }^{1,2}$ while, they are often accompanied by restenosis and occlusion, and the consequential thrombosis is a serious

\footnotetext{
${ }^{a}$ School of Chemical Engineering and Technology, Tianjin University, Weijin Road 92, Tianjin 300072, China. E-mail: jtguo@tju.edu.cn

${ }^{b}$ Collaborative Innovation Center of Chemical Science and Chemical Engineering (Tianjin), Weijin Road 92, Tianjin 300072, China

${ }^{c}$ Key Laboratory of Systems Bioengineering of Ministry of Education, Tianjin University, Weijin Road 92, Tianjin 300072, China

${ }^{d}$ Tianjin University-Helmholtz-Zentrum Geesthacht, Joint Laboratory for Biomaterials and Regenerative Medicine, Weijin Road 92, Tianjin 300072, China

${ }^{e}$ Department of Physiology and Pathophysiology, Logistics University of Chinese People's Armed Police Force, Tianjin 300162, China

$\dagger$ Electronic supplementary information (ESI) available. See DOI: 10.1039/ c4tb02019g
}

threat in patients' recovering period..$^{3-6}$ Therefore, strategies for improving the surface hemocompatibility of artificial vascular grafts are demanded. We have modified artificial vascular grafts by poly(ethylene glycol), gelatin, silk fibroin, and zwitterionic polymers with the aim of minimizing protein adsorption and hindering thrombocyte adhesion. ${ }^{7-15}$ Besides poor hemocompatibility, the delayed or uncompleted endothelialization on the artificial vascular grafts is another major reason for the occurrence of restenosis and thrombosis. Thus, rapid and complete endothelialization of vascular grafts is a radical approach to avoid a series of pathological processes. ${ }^{3,16}$

The transfection of endothelial cells (ECs) has been explored as an effective strategy for endothelialization. ${ }^{17-19}$ A new endothelial layer on implant surfaces can be created rapidly by transfected ECs. For this purpose, the appropriate recombinant genes and gene delivery systems as the primary elements have been widely investigated and developed for EC transfection. For example, the pEGFP-ZNF580 plasmid with the green fluorescent protein 
(abbreviated as pZNF580 plasmid, or pZNF580), coding for angiogenic factors, has been found to accelerate the proliferation and migration of ECs. ${ }^{20,21}$ Our previous studies have demonstrated the superiority and potential application of pZNF580 in the transfection of ECs. ${ }^{22,23}$ Another important task in gene therapy is to seek more efficient carriers for pZNF580 delivery. Nonviral carriers are often used in gene delivery for safety consideration. ${ }^{24,25}$ Several kinds of nonviral carriers including lipid-based materials, polycationic polymers, dendrimers and nanoparticles have been explored in gene delivery and transfection. ${ }^{26-29}$ Among them, poly(ethylenimine) (PEI) is often considered as the gold standard for gene transfection owing to its high charge density capacity, which leads itself to the easy protonation in the acid microenvironment in endosomes/lysosomes. Because the high molecular weight PEI often accompanies significant cytotoxicity, the low molecular weight PEI with low cytotoxicity is widely used in gene transfection research. ${ }^{25,30}$ In order to improve the transfection efficiency of low molecular weight PEI, many researchers have made a great effort for its modification with cyclodextrin, chitosan, cross-linking reagents and metallic or polymeric nanoparticles to obtain low toxic or nontoxic and efficient gene carriers. ${ }^{29,31-33}$ In particularly, the degradable polymeric nanoparticles, which are formed by self-assembly of amphiphilic copolymers, have captured significant attention in gene delivery due to their biosafety and stability. ${ }^{34-37}$ A series of amphiphilic degradable methoxy-poly(ethylene glycol)-blockpoly(depsipeptide-co-cyclic diester)-graft-PEI copolymers have been synthesized by our group, and the corresponding complexes were prepared from these copolymers and pZNF580 plasmids. The results show that the transfection efficiency of these carriers is roughly equivalent with that of the lipofectamine ${ }^{\mathrm{TM}} 2000$ reagent, and the proliferation and migration capability of ECs has been improved greatly after expression by pZNF580. ${ }^{34,35}$

From the above point of view, gene therapy should be considered as an effective strategy for rapid endothelialization. The complexes of polycationic carriers and negatively-charged plasmids can be uptaken through endocytosis, after cellular internalization and endosomal escape, and then the cytoplasm trafficking takes place to initiate plasmid transcription and translation. $^{30,38}$ If EC-targeted receptors are linked with gene carriers, the recognition of the receptor-mediated active gene carriers can enhance cell uptake as well as transfection efficiency.

As an adhesion ligand located in the CS5 site of fibronectin, REDV can be specially recognized by integrin $\alpha 4 \beta 1$. Owing to the large expression of $\alpha 4 \beta 1$ in ECs, the REDV peptide could promote the proliferation and migration of ECs. ${ }^{39,40}$ In 1991, Hubbell and his group proved that REDV modified substrates could selectively improve the attachment and spread ability of ECs, while did not adsorb fibroblasts, vascular smooth muscles cells (SMCs) and platelets. ${ }^{39} \mathrm{Ji}$ et al. also demonstrated that the REDV functionalized heparin/chitosan multilayer specifically promoted EC adhesion and proliferation compared with the multilayer without the REDV peptide. ${ }^{40}$ Choong and his coworkers conjugated REDV with surface-grafted PEGMA polymer brushes (P(PEGMA)-REDV) via atom transfer radical polymerization. Their results showed that the proliferation and attachment of human umbilical vein ECs were increased by the P(PEGMA)-REDV conjugated titanium surface than pristine titanium surfaces. ${ }^{41}$

Generally, the transfection efficiency of ECs mediated by gene complexes is relatively low due to their intrinsic resistance to foreign genes and high sensitivity to the toxic effect. ${ }^{19,42-44}$ Therefore, it is important to develop a special polycationic gene delivery system for improving the transfection efficiency of ECs. To our knowledge, there has been no report about using REDV peptide functionalized polycationic gene carriers for promoting the transfection of ECs yet. It is of great interest to investigate whether the complexes formed by the REDV functionalized polycationic gene carrier and the pZNF580 plasmid are capable of improving the transfection efficiency of ECs.

In this work, a REDV-mediated polycationic gene carrier (mPEG-P(LA-co-CL)-PEI-REDV) was prepared and used for pZNF580 delivery in ECs. The CREDVW (Cys-Arg-Glu-Asp-Val-Trp) peptide was coupled with methoxy poly(ethylene glycol) ether-poly(L-lactideco-e-caprolactone)-PEI block copolymer (mPEG-P(LA-co-CL)-PEI), and the corresponding targeting nanoparticles (REDV-NP) were formed by the self-assembling method. The transfection efficiency of REDV-NP/pZNF580 complexes to ECs was investigated compared with the complexes without the REDV peptide, and the migration capability of ECs transfected by these complexes was also evaluated by scratch wound assay. Fig. 1 shows the schematic illustration of the formation of these REDV-NP and REDV-NP/pZNF580 complexes. Owing to the targeting recognition between REDV-NP/ pZNF580 complexes and $\alpha 4 \beta 1$ integrin in ECs, the increased absorptivity onto ECs mediated by the targeting recognition benefits for the cellular uptake of the complexes, after internalization of the targeting complexes by the potential endocytosis pathway, ${ }^{38,45}$ thus the transfection efficiency could be promoted.

\section{Experiments}

\section{Materials}

Stannous octoate $\left(\mathrm{Sn}(\mathrm{Oct})_{2}\right)$, $\varepsilon$-caprolactone $(99 \%, \mathrm{CL})$ and branched PEI $\left(M_{\mathrm{w}}=1800 \mathrm{Da}\right.$ and $\left.25 \mathrm{kDa}\right)$ were purchased from Sigma-Aldrich and used as received. Methoxy poly(ethylene glycol) ether (mPEG, $M_{\mathrm{w}}=2000 \mathrm{Da}$ ) was also purchased from Sigma-Aldrich and dried in a vacuum prior to use. L-Lactide (LA) was obtained from Foryou Medical Device Co., Ltd (Huizhou, China) and recrystallized twice from ethyl acetate before use. Succinic anhydride, 1, 4-dioxane and triethylamine of analytical grade were obtained from Tianjin Guangfu Chemical Technology Co., Ltd. 1, 4-Dioxane was dried over molecular sieves (type 4A) for $24 \mathrm{~h}$ and distilled prior to use. 4-Dimethylaminopyridine (99\%, DMAP) was purchased from Aladdin Chemical Co. and used as received. $\mathrm{N}$-Hydroxysuccinimide (NHS) and 1-ethyl-3-(3-dimethylaminopropyl) carbodiimide (EDC) were obtained from Shanghai Medpep Co., Ltd. Orthopyridyl disulfide-PEG- $N$-hydroxysuccinimide (OPSS-PEG-NHS, $M_{\mathrm{n}}=2294 \mathrm{Da}$, the $M_{\mathrm{n}}$ of PEG is $2000 \mathrm{Da}$, 99\%) was purchased from JenKem (Beijing) Technology Co., Ltd. CREDVW peptide was supplied by GL Biochem (Shanghai) Ltd. The pZNF580 plasmid was preserved by the Department of physiology and pathophysiology, Logistics University of Chinese People's Armed 


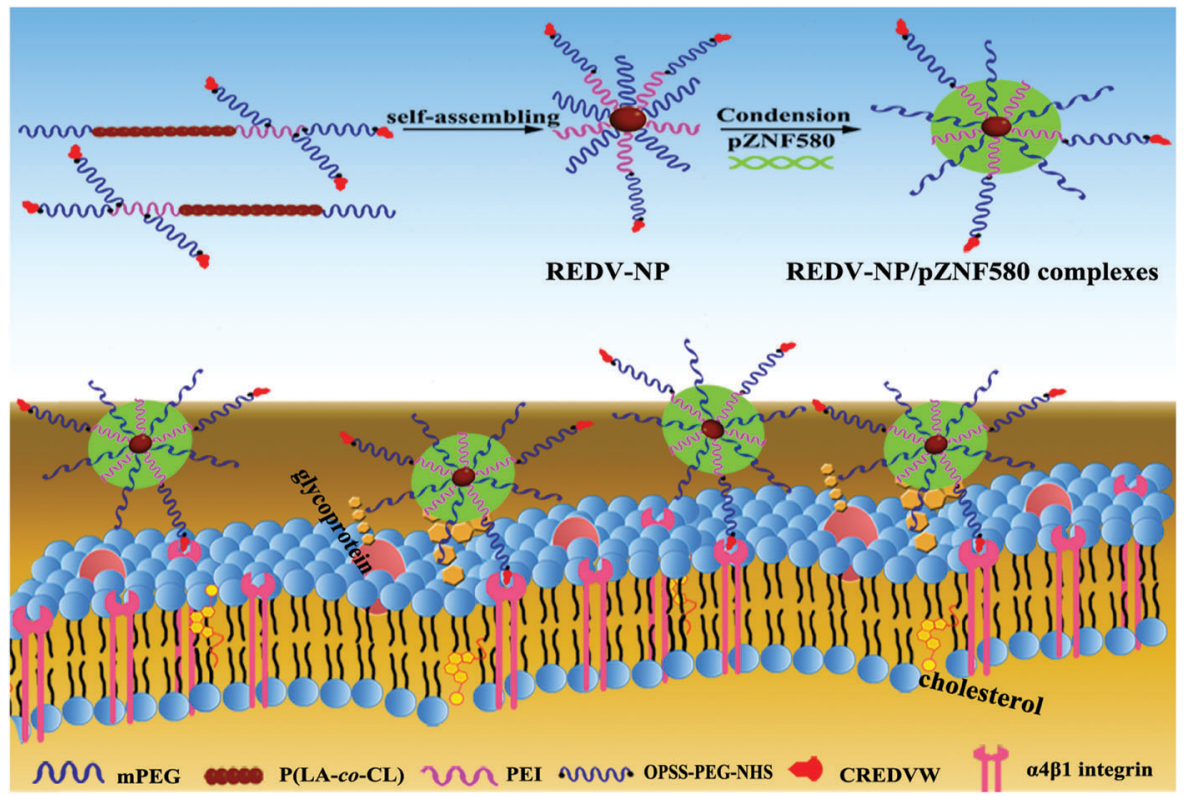

Fig. 1 Schematic illustration of the preparation of REDV-mediated REDV-NP/pZNF580 complexes by the self-assembling method, and recognition of REDV-NP/pZNF580 complexes and integrins in ECs.

Police Force. Rabbit anti-human pZNF580 polyclonal antibody and goat anti-rabbit Ig G were purchased from Abcam (HK) Ltd (Hong Kong, China). The BCA protein assay kit was purchased from Solarbio Science and Technology Co., Ltd (Beijing, China). EA.hy926 ECs were obtained from the Cell Bank of Typical Culture Collection of Chinese Academy of Sciences (Shanghai, China), and cultured in high glucose DMEM supplemented 10\% FBS in $5 \% \mathrm{CO}_{2}$ atmosphere at $37{ }^{\circ} \mathrm{C}$. Other chemicals and reagents of analytical grade were obtained from Tianjin Guangfu Chemical Technology Co., Ltd.

\section{Synthesis of the mPEG-P(LA-co-CL) copolymer}

mPEG-P(LA-co-CL) copolymer was synthesized by ring-opening polymerization (ROP) of LA and CL using MPEG as an initiator and $\mathrm{Sn}(\mathrm{Oct})_{2}$ as a catalyst. The purified and dried $\mathrm{mPEG}(200 \mathrm{mg}$, $0.1 \mathrm{mmol})$ was introduced into an anhydrous Schlenk flask under nitrogen gas, a predetermined amount of LA $(0.288 \mathrm{~g}$, $2 \mathrm{mmol}), \mathrm{CL}(0.74 \mathrm{~mL}, 6.89 \mathrm{mmol})$ and $\mathrm{Sn}(\mathrm{Oct})_{2}$ catalyst $(3 \mu \mathrm{L}$, $0.009 \mathrm{mmol}$ ) were added subsequently, then the flask was sealed and operated at $120{ }^{\circ} \mathrm{C}$ for $24 \mathrm{~h}$. After the reaction mixture was cooled to room temperature, methylene chloride was added for dilution, and the obtained mixture was added dropwise into cold diethyl ether. The resultant precipitate mPEG-P(LA-co-CL) was filtered and dried under vacuum.

\section{Synthesis of the MPEG-P(LA-co-CL)-COOH copolymer}

mPEG-P(LA-co-CL)-COOH copolymer was obtained by succinylation of mPEG-P(LA-co-CL). mPEG-P(LA-co-CL) (1.0 g, 0.12 mmol), DMAP (0.073 g, $0.6 \mathrm{mmol})$, succinic anhydride (0.060 g, $0.6 \mathrm{mmol})$, and triethylamine ( $30 \mu \mathrm{L}, 0.2 \mathrm{mmol})$ were dissolved in $30 \mathrm{~mL}$ anhydrous 1, 4-dioxane, then the solution was kept at room temperature for $24 \mathrm{~h}$ under a nitrogen atmosphere. After condensing to $c a .10 \mathrm{~mL}$ by a rotary vacuum evaporator, the viscous solution was dropped into cold diethyl ether and the white crude product was obtained by precipitation. The product was dissolved by methylene chloride again, and washed with $0.01 \mathrm{M}$ sodium carbonate solution, $0.1 \mathrm{M}$ hydrochloric acid solution, 1.0 M sodium chloride solution and deionized (DI) water in the order, then the pure mPEG-P(LA-co-CL)$\mathrm{COOH}$ polymer can be received after drying in a vacuum oven at room temperature.

\section{Synthesis of the mPEG-P(LA-co-CL)-PEI copolymer}

PEI 1800 Da modified mPEG-P(LA-co-CL)-COOH was prepared by amidation reaction between the amino group of PEI and the carboxyl group of mPEG-P(LA-co-CL)-COOH. mPEG-P(LA-co-CL)$\mathrm{COOH}(0.1 \mathrm{~g} 11.9 \mu \mathrm{mol})$, NHS $(6.85 \mathrm{mg}, 59.5 \mu \mathrm{mol})$ and EDC (11.4 mg, $59.5 \mu \mathrm{mol})$ were dispersed into dimethyl sulphoxide (DMSO), and the solution was performed at ambient temperature for $2 \mathrm{~h}$ under nitrogen atmosphere. Then the mixture was dripped into the PEI solution $(89.3 \mathrm{mg}, 49.6 \mu \mathrm{mol})$ and carried out for $18 \mathrm{~h}$ under a nitrogen atmosphere. The residue was dialyzed with a dialysis tube (MWCO $=7 \mathrm{kDa}$ ) for $48 \mathrm{~h}$ and then freeze dried for further use.

\section{Synthesis of the mPEG-P(LA-co-CL)-PEI-REDV copolymer}

The CREDVW peptide was conjugated with mPEG-P(LA-co-CL)PEI using the linker of OPSS-PEG-NHS ( $c f$. Scheme 1). First, the mPEG-P(LA-co-CL)-PEI (100 mg, $9.82 \mu \mathrm{mol})$ and OPSS-PEG-NHS $(16.4 \mathrm{mg}, 8.22 \mu \mathrm{mol})$ were reacted in a mixture of $4 \mathrm{~mL}$ PBS $(\mathrm{pH}=7.4,0.1 \mathrm{M})$ and $2 \mathrm{~mL}$ DMSO for $2 \mathrm{~h}$ in the dark. Then the CREDVW peptide $(4.63 \mathrm{mg}, 5.75 \mu \mathrm{mol})$ dissolved in $1 \mathrm{~mL}$ of PBS was dripped slowly into the solution with stirring in the dark for another $4 \mathrm{~h}$. The mixtures were dialyzed against DI water using a dialysis membrane (MWCO $=7 \mathrm{kDa}$ ) for $48 \mathrm{~h}$ and subsequently lyophilized. 

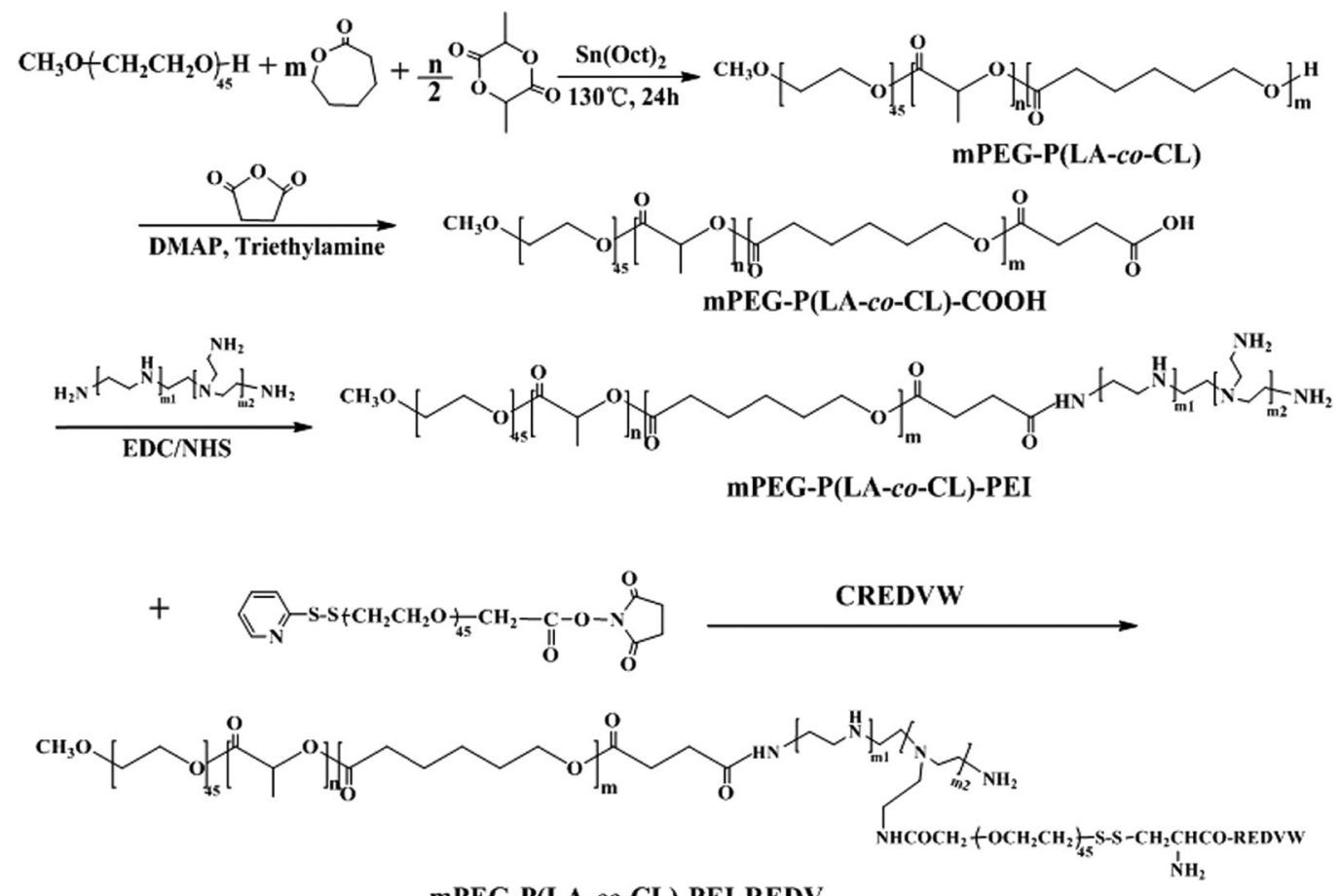

mPEG-P(LA-co-CL)-PEI-REDV

Scheme 1 Synthesis route of the REDV-mediated polycationic gene carrier mPEG-P(LA-CO-CL)-PEI-REDV.

\section{Preparation of nanoparticles}

The dialysis method was used to prepare two kinds of nanoparticles from mPEG-P(LA-co-CL)-PEI and mPEG-P(LA-co-CL)-PEI-REDV polymers. $10 \mathrm{mg}$ of mPEG-P(LA-co-CL)-PEI or mPEG-P(LA-co$\mathrm{CL}$ )-PEI-REDV polymer was dissolved in a $5 \mathrm{~mL}$ DMSO solution under stirring, then the solution was transferred into the dialysis tube (MWCO $=7 \mathrm{kDa}$ ) for dialysis against DI water at an uniform speed. The received mPEG-P(LA-co-CL)-PEI and mPEG-P(LA-coCL)-PEI-REDV nanoparticles were abbreviated as NP and REDV$\mathrm{NP}$, respectively.

\section{Preparation of NP/pZNF580 and REDV-NP/pZNF580 complexes}

The pZNF580 plasmid was deliquesced to $60 \mu \mathrm{g} \mathrm{mL}^{-1}$ by $0.01 \mathrm{M}$ PBS ( $\mathrm{pH}=7.4)$. Complexes were prepared by mixing the nanoparticle suspension $\left(1 \mathrm{mg} \mathrm{mL}^{-1}\right)$ with plasmid solution at different N/P molar ratios by vortex and incubated for $30 \mathrm{~min}$ before use.

\section{Agarose gel electrophoresis}

The electrophoretic mobility of the NP/pZNF580 and REDV-NP/ pZNF580 complexes was examined by agarose gel electrophoresis. First, NP/pZNF580 and REDV-NP/pZNF580 complexes at various N/P molar ratios were prepared according to the above method. Followed by the addition of $5 \mu \mathrm{L}$ of $6 \times$ ethidium bromide agarose loading dye for culturing another $10 \mathrm{~min}$, then the prepared samples were run with a $0.8 \%$ agarose gel in $1 \times$ TAE buffer at $100 \mathrm{~V}$ for $40 \mathrm{~min}$. The UV illuminator was used to show the location of the pZNF580 plasmid.

\section{Protection of the pZNF580 plasmid}

To investigate pZNF580 plasmid integrity in the NP/pZNF580 and REDV-NP/pZNF580 complexes, naked pZNF580 plasmid, NP/pZNF580 and REDV-NP/pZNF580 complexes with the same pZNF580 content $(0.8 \mu \mathrm{g})$ at a $\mathrm{N} / \mathrm{P}$ molar ratio of 10 were separately incubated with $1 \mu \mathrm{L}$ of PBS or deoxyribonuclease (DNase I) reaction buffer ( 0.1 unit $\mu \mathrm{L}^{-1}, 50 \mathrm{mM}$ Tris- $\mathrm{HCl}, \mathrm{pH}=$ 7.5 and $25 \mathrm{mM} \mathrm{MgCl}_{2}$ ) at $37{ }^{\circ} \mathrm{C}$ for $30 \mathrm{~min}$. For DNase I inactivation and DNA release, all samples were treated with $5 \mu \mathrm{L}$ of $500 \mathrm{mM}$ EDTA and heated at $70{ }^{\circ} \mathrm{C}$ for $10 \mathrm{~min}$. Then all the samples were cultured for $60 \mathrm{~min}$ at $37{ }^{\circ} \mathrm{C}$ to release DNA. After addition of $2 \mu \mathrm{L}$ of $6 \times$ agarose loaded with ethidium bromide dye, the mixture solutions were incubated for another $10 \mathrm{~min}$. Finally, the samples were electrophoresed through a $0.8 \%$ agarose gel in $1 \times$ TAE buffer at $100 \mathrm{~V}$ for $40 \mathrm{~min}$. The gel was recorded using an UV illuminator for the location of pZNF580.

\section{In vitro cytotoxicity}

EA.hy926 cells were used to evaluate the cytotoxicity of NP/pZNF580 and REDV-NP/pZNF580 complexes by the MTT assay with branched PEI $1800 \mathrm{Da}$ and PEI $25 \mathrm{kDa}$ as controls. After EA.hy926 cells $\left(1 \times 10^{4}\right.$ cell per well) were seeded in 96-well plates and cultured for $24 \mathrm{~h}$ in a $5 \% \mathrm{CO}_{2}$ atmosphere, the NP/pZNF580, REDV-NP/ pZNF580 and PEI $25 \mathrm{kDa} /$ pZNF580 complexes at different pZNF580 plasmid concentrations $\left(3 \mu \mathrm{g} \mathrm{mL} \mathrm{m}^{-1}, 6 \mu \mathrm{g} \mathrm{mL} \mathrm{m}^{-1}\right.$, $9 \mu \mathrm{g} \mathrm{mL} L^{-1}, 12 \mu \mathrm{g} \mathrm{mL} L^{-1}, 15 \mu \mathrm{g} \mathrm{mL}^{-1}$ ) were added into the medium. After $48 \mathrm{~h}, 20 \mu \mathrm{L}$ of MTT ( $5 \mathrm{mg} \mathrm{mL} \mathrm{mL}^{-1}$ in PBS) was added into each well for the formation of formazan crystals. Then $200 \mu \mathrm{L}$ DMSO was mixed with the solution to dissolve the fomazan crystal by 
vortex gently. Optical density (OD) was measured using an ELISA reader (Titertek multiscan) at the wavelength of $490 \mathrm{~nm}$. The cell viability (\%) was determined by the formula:

$$
\text { Cell viability }(\%)=\frac{\mathrm{OD}_{\text {sample }}}{\mathrm{OD}_{\text {control }}} \times 100
$$

where $\mathrm{OD}_{\text {sample }}$ represents an $\mathrm{OD}$ value of cells treated with gene carrier/plasmid complexes and $\mathrm{OD}_{\text {control }}$ represents cells treated with medium only. Each experiment was performed at six independent times.

\section{In vitro transfection}

The transfection efficiency of NP and REDV-NP gene carriers was compared with that of branched PEI 1800 Da and PEI $25 \mathrm{kDa}$. EA.hy926 cells were seeded in 24 -well plates at an initial density of $1 \times 10^{5}$ cell per well and cultured for $24 \mathrm{~h}$ to reach $70-80 \%$ confluence before transfection. The medium was changed with serum-free media after $12 \mathrm{~h}$, and then PEI 1800 Da/pZNF580, PEI 25 kDa/pZNF580, NP/pZNF580 and REDV-NP/ pZNF580 complexes at the N/P molar ratio of 10 with the pZNF580 concentration of $1 \mu \mathrm{g}$ per well were added into different wells for additional incubation for $4 \mathrm{~h}$. After replacing with fresh growth medium (DMEM with 10\% FBS), the levels of green fluorescent protein (GFP) expressed by pZNF580 in cells were performed using a confocal laser-scanning microscope.

\section{Western blot analysis}

Total protein expressed by pZNF580 was obtained with RIPA lysis buffer. The concentration of the lysate was determined by a BCA protein assay kit. Target protein concentrations were determined by western blot analysis. First, proteins (100 mg per lane) were separated using $15 \%$ sodium dodecylsulfate polyacrylamide gel for electrotransferring onto a nitrocellulose membrane. Second, the proteins were transferred onto polyvinylidene fluoride membranes and hybridized with rabbit anti-human pZNF580 polyclonal antibody overnight. After incubating with the horseradish peroxidase-conjugated secondary antibody for $1 \mathrm{~h}$, the proteins were developed with the enhanced chemiluminescence (ECL) system. The $\beta$-actin antibody was used as a control. All lanes were analyzed by "Image J" software for their areas and mean gray values.

\section{Cell migration}

Migration of EA.hy926 cells transfected by NP/pZNF580, REDVNP/pZNF580, PEI $1800 \mathrm{Da} /$ pZNF580 and PEI $25 \mathrm{kDa} /$ pZNF580 complexes at the N/P molar ratio of 10 was evaluated by a wound healing assay. Briefly, the monolayer EA.hy926 cells treated with nothing or four complexes with a pZNF580 concentration of $1 \mu \mathrm{g}$ per well were incubated in 6-well plates, and then scratched at the middle of each well with a $200 \mathrm{~mL}$ sterile pipette tip. Cells in three parallel wells were photographed by an inverted fluorescence microscopy in three fields per well. Cells were incubated using D-Hanks buffer $(\mathrm{pH}=7.4)$ for $12 \mathrm{~h}$. The same fields were captured again at different time points $(0,6$ and $12 \mathrm{~h})$ for the widths of the scratches. The recovered surface areas of the cells cultured for $12 \mathrm{~h}$ were calculated by
"Image J" software. The relative recovered surface area (\%) was calculated by the following formula: the relative recovered surface area $(\%)=$ the recovered surface area/the total wounded area.

\section{Characterization}

${ }^{1} \mathrm{H}$ NMR spectra were characterized using a Bruker Avance spectrometer (AV-400, Bruker, Karlsruche, Gemany) with $\mathrm{CDCl}_{3}$-d as a solvent. FTIR spectra were recorded with WQF-510A/520A FTIR (Beijing Beifen-Ruili Analytical Instrument Co., Ltd). The hydrodynamic diameter of the nanoparticles was analyzed by dynamic light scattering (DLS) using a Nano Particle Size Analyzer (Beckman Coulter Instruments, USA). The size and morphology of the dried nanoparticles were determined using a transmission electron microscope (TEM) using a Japanese model JEM-2100F at $200 \mathrm{kV}$ accelerating voltages. The CREDVW peptide immobilized on the amphiphilic block copolymer was characterized using a fluorescence spectrometer (Varian Cary Eclipse fluorescence spectrometer) based on the emission wavelength of $360 \mathrm{~nm}$, the excitation wavelength of $296 \mathrm{~nm}$, the excitation slit width and emission slit width of $5 \mathrm{~nm}$. All samples were dissolved in the mixed solution of PBS $(\mathrm{pH}=8.4)$ and DMSO $(3: 2, \mathrm{v}: \mathrm{v})$. The Olympus FV1000 confocal laser-scanning microscope was used to indicate the expression levels of GFP in EA.hy926 cells with a 60 objective lens. Olympus CKX41 inverted fluorescent microscope was used to evaluate the migration ability of EA.hy926 cells mediated by different complexes.

\section{Statistics}

Student's $t$-test was used to analyze the differences between data sets. Data on graphs were reported as mean \pm SD (standard deviation of the mean value) unless indicated otherwise. $P \leq 0.05$, $P \leq 0.01$ and $P \leq 0.001$ were considered as significant, greater significant and significantly higher levels, respectively.

\section{Results}

\section{Synthesis and characterization of the MPEG-P(LA-co-CL)-PEI- REDV copolymer}

Fig. 2A shows the ${ }^{1} \mathrm{H}$ NMR spectrum of the mPEG-P(LA-co-CL) copolymer in $\mathrm{CDCl}_{3}$. The characteristic peak at 3.67 ppm was attributed to the methylene of MPEG in the block copolymer. The characteristic peak of methine and methyl groups in the PLA chain appeared at $5.20 \mathrm{ppm}$ and $1.68 \mathrm{ppm}$ in the ${ }^{1} \mathrm{H}$ NMR spectrum, respectively. The major resonance signals at $4.10 \mathrm{ppm}$ $\left(-\mathrm{OCH}_{2}\left(\mathrm{CH}_{2}\right)_{3} \mathrm{CH}_{2} \mathrm{CO}-, 2 \mathrm{H}\right), 2.36 \mathrm{ppm}\left(-\mathrm{OCH}_{2}\left(\mathrm{CH}_{2}\right)_{3} \mathrm{CH}_{2} \mathrm{CO}-\right.$, $2 \mathrm{H}), 1.68 \mathrm{ppm}$ and $1.41 \mathrm{ppm}\left(-\mathrm{OCH}_{2}\left(\mathrm{CH}_{2}\right)_{3} \mathrm{CH}_{2} \mathrm{CO}-, 6 \mathrm{H}\right)$ were ascribed to the PCL chain. The $M_{\mathrm{n}}$ of the P(LA- $\left.\mathrm{Co}-\mathrm{CL}\right)$ copolymer segment was calculated by the relative intensity ratio of the peaks at $5.20 \mathrm{ppm}$ and $4.10 \mathrm{ppm}$ to the peak at $3.67 \mathrm{ppm}$, respectively. The repeat units of LA and CL were determined to be 10 and 32. So the $M_{\mathrm{n}}$ of mPEG-P(LA-co-CL) measured by ${ }^{1} \mathrm{H}$ NMR was about 6400 Da.

The ${ }^{1} \mathrm{H}$ NMR spectrum of mPEG-P(LA-co-CL)-COOH with assignments was shown in Fig. 2B. Besides the characteristic 

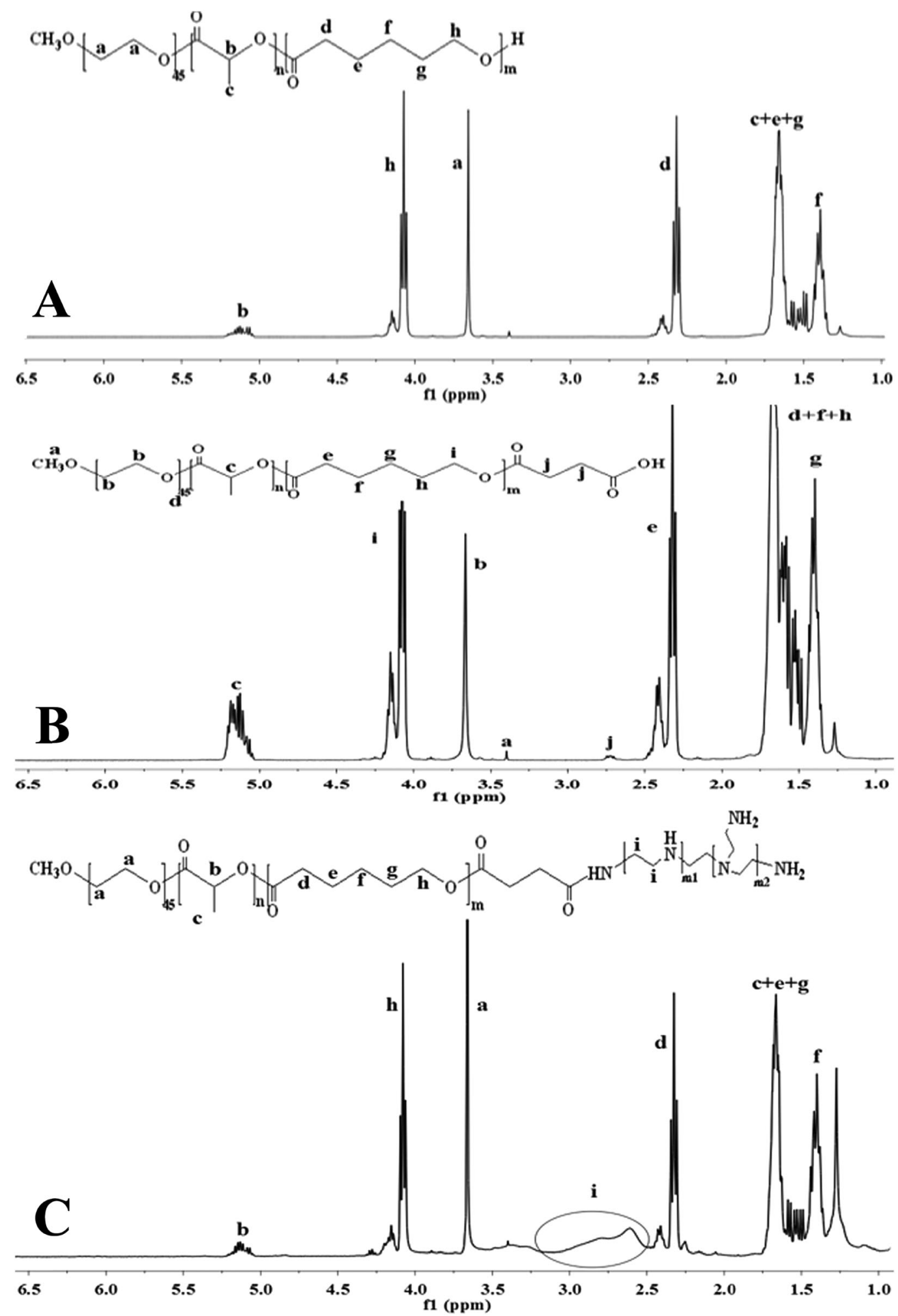

Fig. $2{ }^{1} \mathrm{H}$ NMR spectra of mPEG-P(LA-CO-CL) (A), mPEG-P(LA-CO-CL)-COOH (B), and mPEG-P(LA-CO-CL)-PEI (C).

peaks of mPEG-P(LA-co-CL), new appearance of the peak at $2.67 \mathrm{ppm}$ assigned to the methylene protons of succinimide residue. According to the relative integral area ratio of the peak at $2.67 \mathrm{ppm}$ to the peak at $3.67 \mathrm{ppm}$, the number of succinimide residue in each $\mathrm{mPEG}-\mathrm{P}(\mathrm{LA}-\mathrm{co}-\mathrm{CL})-\mathrm{COOH}$ was approximately 1 , indicating that the hydroxyl-terminated mPEG-P(LA-co-CL) was succinylated completely.

In Fig. 2C, a broad peak at 2.52-3.23 ppm was assigned to the methylene protons $\left(-\mathrm{CH}_{2} \mathrm{CH}_{2} \mathrm{NH}-\right)$ of the PEI block, and the other characteristic peaks were ascribed to the protons of 
Table $1 M_{n}$ of mPEG-P(LA-CO-CL), mPEG-P(LA-CO-CL)-COOH and mPEG-P(LA-CO-CL)-PEI measured by ${ }^{1} \mathrm{H}$ NMR

\begin{tabular}{ll}
\hline Samples & $M_{\mathrm{n}}(\mathrm{Da})$ \\
\hline mPEG-P(LA-co-CL) & 6400 \\
mPEG-P(LA-co-CL)-COOH & 6500 \\
mPEG-P(LA-co-CL)-PEI & 8300
\end{tabular}

segments correspondingly, demonstrating that amphiphilic block copolymer mPEG-P(LA-co-CL)-PEI was synthesized successfully. The $M_{\mathrm{n}}$ of mPEG-P(LA- $\left.c o-\mathrm{CL}\right)$, mPEG-P(LA- $\left.c o-\mathrm{CL}\right)-\mathrm{COOH}$ and mPEG-P(LA-co-CL)-PEI measured by ${ }^{1} \mathrm{H}$ NMR was summarized in Table 1.

The FTIR spectra of mPEG-P(LA- $c o-\mathrm{CL})$, mPEG-P(LA-co-CL)$\mathrm{COOH}$ and mPEG-P(LA-co-CL)-PEI were shown in Fig. 3. For mPEG-P(LA-co-CL), the strong absorption band at around $1741 \mathrm{~cm}^{-1}$ was due to the characteristic stretching vibration band of $\mathrm{C}=\mathrm{O}$ bonds. $1178 \mathrm{~cm}^{-1}$ and $1100 \mathrm{~cm}^{-1}$ were ascribed to the $-\mathrm{C}-\mathrm{O}-$ stretching vibrations of the ester groups in MPEG-P(LA-co-CL). $2946 \mathrm{~cm}^{-1}$ corresponded to the stretching vibrations of the $\mathrm{C}-\mathrm{H}$ bond. After succinylation, the characteristic adsorption band of $\mathrm{C}=\mathrm{O}$ bonds in mPEG-P(LA-co-CL)-COOH was a slight shift compared with that of the mPEG-P(LA-co-CL). The significant peaks of $3446 \mathrm{~cm}^{-1}$ and $1646 \mathrm{~cm}^{-1}$ of the N-H stretching vibration and bending vibration of amino groups were observed in the FTIR spectrum of mPEG-P(LA-co-CL)-PEI, which confirmed that branched PEI has been grafted on mPEG-P(LA-co-CL)-COOH via the amidation reaction.

The reaction of OPSS-PEG-NHS with primary amino groups of PEI resulted in the introduction of the dithiopyridyl group through amidation, and then the CREDVW peptide with sequence Cys-Arg-Glu-Asp-Val-Trp was covalently conjugated to PEI via the reaction of disulfide linkage between dithiopyridyl and the sulfhydryl group of cysteine. The fluorescence spectrum was used to identify the grafting of the CREDVW peptide via the

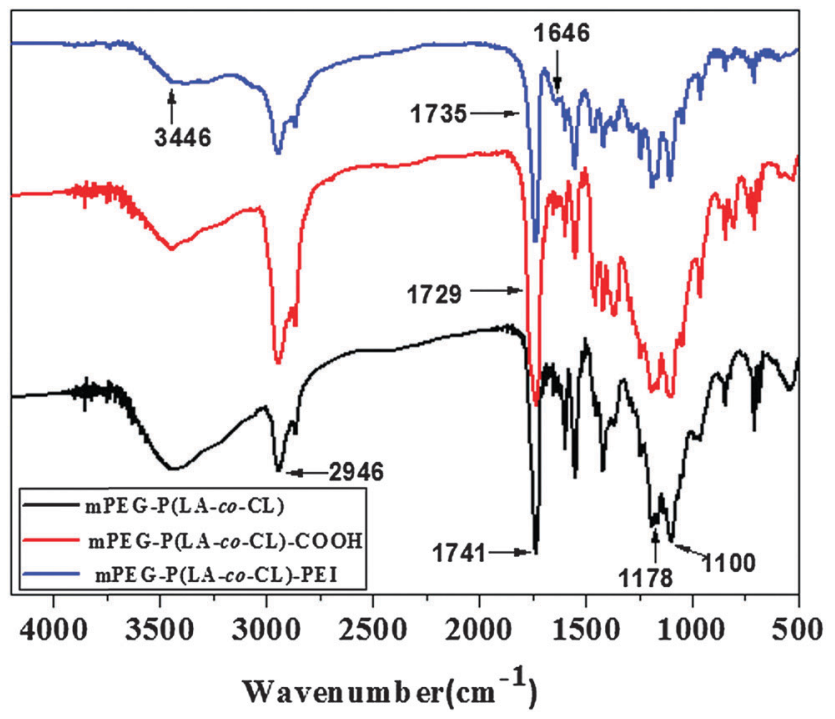

Fig. 3 FTIR spectra of mPEG-P(LA-CO-CL), mPEG-P(LA-CO-CL)-COOH and $\mathrm{mPEG}-\mathrm{P}(\mathrm{LA}-\mathrm{CO}-\mathrm{CL})-\mathrm{PEI}$.

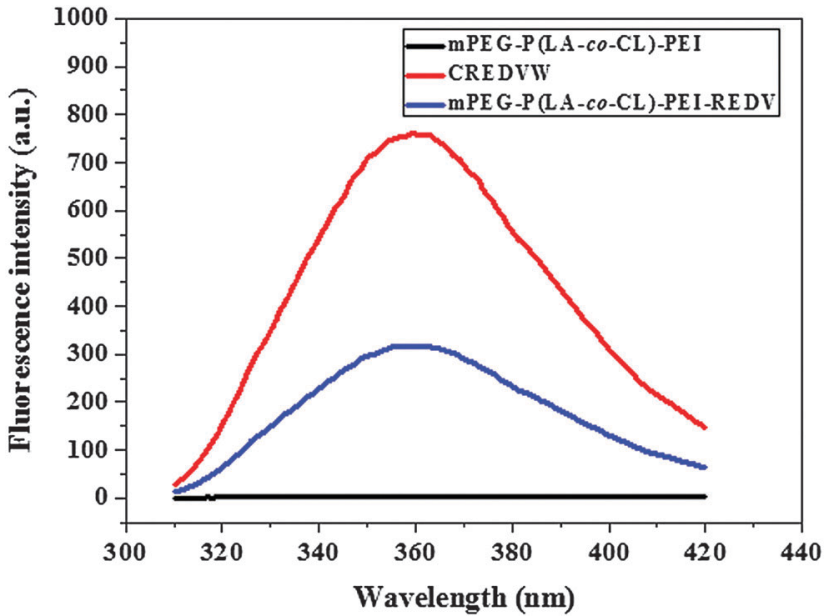

Fig. 4 Fluorescence spectra of the CREDVW peptide, mPEG-P(LA-Co-CL)$\mathrm{PEI}$ and $\mathrm{mPEG}-\mathrm{P}(\mathrm{LA}-\mathrm{CO}-\mathrm{CL})-\mathrm{PEI}-\mathrm{REDV}$.

emission spectrum of tryptophane residues at $360 \mathrm{~nm}$. Fig. 4 shows the fluorescence spectra of the CREDVW peptide $\left(0.15 \mathrm{mg} \mathrm{mL}^{-1}\right)$ and mPEG-P(LA-co-CL)-PEI-REDV $\left(0.78 \mathrm{mg} \mathrm{mL}^{-1}\right)$ with mPEG-P(LA$c o$-CL)-PEI $\left(0.50 \mathrm{mg} \mathrm{mL}^{-1}\right)$ as a reference. Both mPEG-P(LA-co-CL)PEI-REDV and CREDVW peptides exhibited a characteristic emission peak at $360 \mathrm{~nm}$ in the spectra, indicating that the CREDVW peptide has been grafted onto the amphipathic block copolymer mPEG-P(LA- $c o$-CL)-PEI. The content of the CREDVW peptide on the mPEG-P(LA-co-CL)-PEI-REDV was $7 \mathrm{wt} \%$, determined by an established calibration curve of the fluorescence spectrum intensity $(y)$ versus the concentrations of CREDVW (C) under the same conditions $\left(y=5429.3 \mathrm{C}\left(\mathrm{mg} \mathrm{mL}^{-1}\right)+12.3\right.$, $\left.\left(R^{2}=0.999\right)\right)$.

\section{The sizes and morphologies of the nanoparticles and their complexes with pZNF580}

TEM was applied to characterize the sizes and morphologies of the nanoparticles and their complexes with pZNF580. Fig. 5A and C show the images of the dried NPs and REDV-NPs, respectively. Ellipsoidal particles were observed in these two micrographs and the diameters were $54.3 \pm 11.5 \mathrm{~nm}$ and $56.1 \pm 8.2 \mathrm{~nm}$. After forming complexes with pZNF580 $(\mathrm{N} / \mathrm{P}$ molar ratio $=10)$, the sizes of NPs and REDV-NPs became $58.2 \pm 11.8 \mathrm{~nm}$ and $64.3 \pm 19.6 \mathrm{~nm}$, respectively (Fig. 5B and D). The REDV-NP complexes were slightly larger than NP complexes, while their morphologies were basically similar with each other.

\section{The hydrodynamic diameters and zeta potentials of the nanoparticles and their complexes}

The hydrodynamic diameter of REDV-NP was $c a .97 .4 \mathrm{~nm}$, determined by the DLS technique, and a nearly normal fashion between $30 \mathrm{~nm}$ to $300 \mathrm{~nm}$ was illustrated in Fig. 6 . The inset of Fig. 6 shows the aqueous suspension of REDV-NP without (A) and with (B) a beam, respectively. It can be clearly observed that the stable and blue-emitting nanoparticle suspension has been obtained by the dialysis method. When the nanoparticle suspension was illuminated by a beam of light $(\lambda=650 \mathrm{~nm})$, a bright "pathway" 


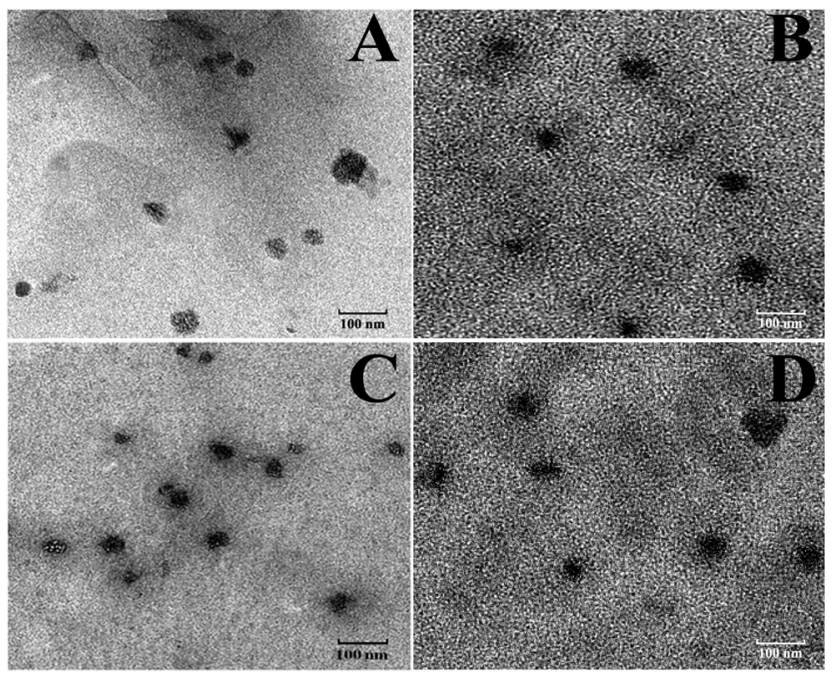

Fig. 5 TEM images of NPs (A), NP/pZNF580 complexes at an N/P molar ratio of 10 (B), REDV-NP (C) and REDV-NP/pZNF580 complexes at an N/P molar ratio of 10 (D).

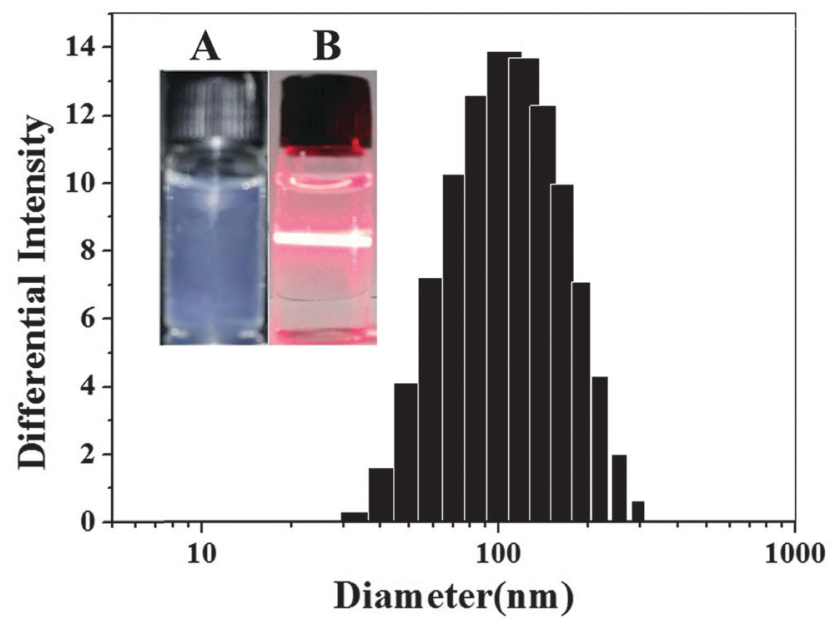

Fig. 6 DLS histogram of REDV-NP suspension. Inset: the aqueous suspension of REDV-NPs without (A) and with (B) a beam ( $\lambda=650 \mathrm{~nm})$.

can be found caused by the light scattering of the colloidal particles. This "Tyndall effect" 46,47 approved that the REDV-NP micelles have been formed by self-assembly of MPEG-P(LA-coCL)-PEI-REDV block copolymers.

The zeta potential of NP was $18.8 \pm 6.6 \mathrm{mV}$ (Fig. S1A, ESI $\dagger$ ), a little larger than that of REDV-NPs $(16.4 \pm 6.5 \mathrm{mV}$, Fig. S1B, ESI $\dagger)$. This is probably due to the conjugation of the CREDVW peptide (7 wt\%) with mPEG-P(LA-co-CL)-PEI copolymer, which would decrease the content of amino groups, thus reducing the positive charge of self-assembling nanoparticles.

Fig. 7 shows the hydrodynamic diameters and zeta potentials of REDV-NP/pZNF580 complexes at different N/P molar ratios measured by DLS. The size of complexes was $210.7 \pm 9.2 \mathrm{~nm}$ when the N/P molar ratio was 2.5 , while the size increased to $236.5 \pm 7.8 \mathrm{~nm}$ at $\mathrm{N} / \mathrm{P}=5$. The following size values decreased greatly when the N/P molar ratio increased further from 5 to 15 ,

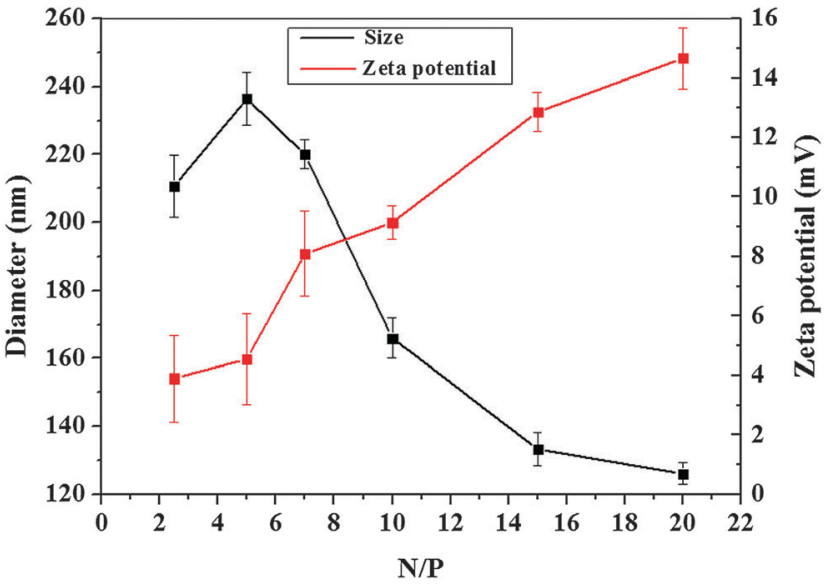

Fig. 7 Hydrodynamic diameters and zeta potentials of REDV-NP/ pZNF580 complexes at different N/P molar ratios, all the samples were prepared in PBS $(\mathrm{pH}=7.4,0.1 \mathrm{M})$ and the measurements were performed in triplicates.

and subsequently they showed a slow decrease with the N/P molar ratio being changed from 15 to 20 . It can be inferred that the ability of condensing the pZNF580 plasmid by REDV-NPs was low at the N/P molar ratio between 2.5 and 5, thus they formed large particles. With the increase of the N/P molar ratio, the compressing ability of REDV-NP increased gradually, so the size of the complexes became smaller and smaller. When the N/P molar ratio exceeded 15, pZNF580 condensing capability of REDV-NP tended to be stable, and the size of their complexes did not change greatly. The zeta potential of REDV-NP/pZNF580 complexes rose from $3.8 \mathrm{mV}$ to $14.7 \mathrm{mV}$ with the increase of the $\mathrm{N} / \mathrm{P}$ molar ratio from 2.5 to 20 . The positively-charged zeta potential of complexes was just required for transfection in vitro, which consequently facilitated cell uptake. ${ }^{48,49}$

\section{Agarose gel electrophoresis}

Naked pZNF580 with negatively-charged phosphate groups could migrate easily from cathode to anode under electric field in agarose gel electrophoresis. But electrophoretic mobility shift of plasmid would be retarded or diminished when it was encapsulated by polycationic carriers. As shown in Fig. 8, pZNF580 plasmids were retarded by both NP and REDV-NP gene carriers with the increase of the N/P molar ratio. Furthermore, the migration of pZNF580 was completely retarded at the $\mathrm{N} / \mathrm{P}$ molar ratio of 5 and 10 by the NP and REDV-NP carriers,
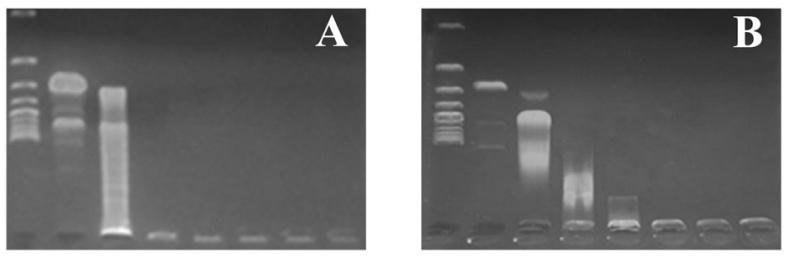

$\begin{array}{llllllllllllll}\text { Marker } 0 & 1 & 5 & 10 & 15 & 20 & 30 & \text { Marker } 0 & 1 & 3 & 5 & 10 & 15 & 20\end{array}$

Fig. 8 Agarose gel electrophoresis of the NP/pZNF580 complexes (A) and REDV-NP/pZNF580 complexes (B) at different N/P molar ratios. 
respectively, suggesting that there was a little difference between the NPs and REDV-NPs in the ability of compressing the plasmid. This may be due to their different zeta potential values. In order to ensure the stability of NP and REDV-NP complexes, the $\mathrm{N} / \mathrm{P}$ molar ratio of 10 was selected preferentially in the following study when it was not described in detailed.

\section{Protection of the pZNF580 plasmid}

The gel retardation assay was performed to study the stability of the polycationic nanoparticle/plasmid complexes against degradation by nucleases. Fig. 9 shows the gel retardation assay results of the naked pZNF580 (lane B), NP/pZNF580 (lane C) and REDV-NP/pZNF580 complexes (lane D) incubated with DNase I, and two control groups of NP/pZNF580 complexes (lane E) and REDV-NP/pZNF580 complexes (lane F) without DNase I treatment. There was no shift of lane $\mathrm{E}$ and lane $\mathrm{F}$ because the migration of pZNF580 was completely retarded by the NP and REDV-NP carriers at a N/P molar ratio of 10 . The naked pZNF580 treated with DNase I (lane B) did not show any band because of its complete degradation by nucleases, while, the pZNF580 was efficiently protected from enzymatic hydrolysis by both NP and REDV-NP carriers. It suggested that the NP/pZNF580 and REDV-NP/pZNF580 complexes were stable against nucleolytic degradation by DNase I, indicating that both NPs and REDV-NPS can be potential candidates for pZNF580 plasmid delivery.

\section{In vitro cytotoxicity}

The cytotoxicity of PEI 1800 Da/pZNF580, NP/pZNF580, REDVNP/pZNF580 and PEI $25 \mathrm{kDa} /$ pZNF580 complexes with different concentrations was evaluated by cell viability based on the MTT assay (Fig. 10). When the pZNF580 plasmid concentration was the same in different groups, the relative cell viability in the NP/ pZNF580 and REDV-NP/pZNF580 complex groups was higher than that of PEI $1800 \mathrm{Da} /$ pZNF580 complex group, much more than the PEI $25 \mathrm{kDa} / \mathrm{pZNF} 580$ complexes. With the increase of the pZNF580 plasmid concentration, the relative cell viability

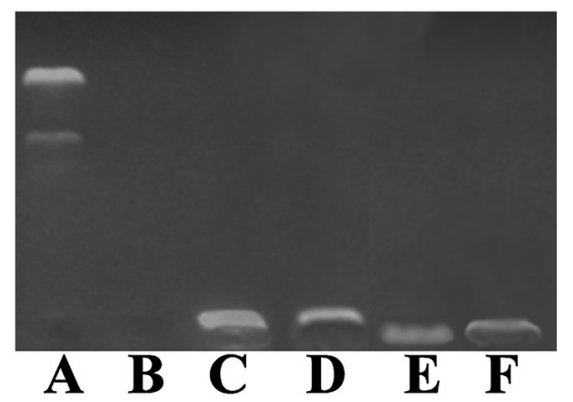

Fig. 9 The effect of DNase I on pZNF580 by the gel retardation assay after incubation with and without DNase I reaction buffer at $37{ }^{\circ} \mathrm{C}$ for 30 min. Lane A: naked pZNF580 without DNase I as standard; lane B: naked pZNF580 plasmid treated with DNase I; lane C: NP/pZNF580 complexes (N/P molar ratio of 10 ) treated with DNase I; lane D: REDV-NP/pZNF580 complexes (N/P molar ratio of 10 ) treated with DNase I; lane E: NP/ pZNF580 complexes (N/P molar ratio of 10) treated without DNase I; lane F: REDV-NP/pZNF580 complexes (N/P molar ratio of 10) treated without DNase I.

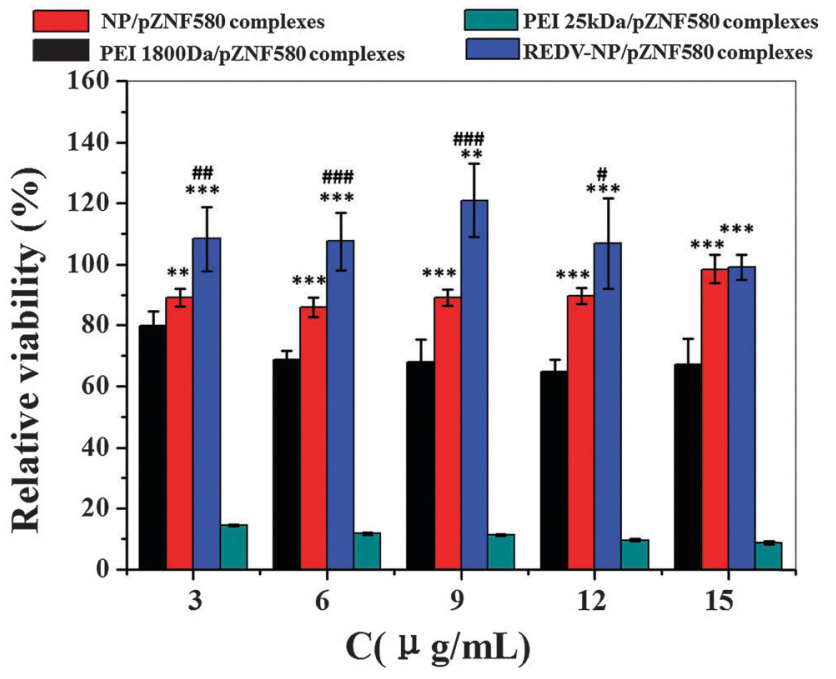

Fig. 10 Relative cell viability of EA.hy926 cells in the presence of PEI 1800 Da/pZNF580, NP/pZNF580, REDV-NP/pZNF580 and PEI 25 kDa/pZNF580 complexes at a N/P molar ratio of 10 with different pZNF580 plasmid concentrations $\left(3 \mu \mathrm{g} \mathrm{mL}^{-1}, 6 \mu \mathrm{g} \mathrm{mL}^{-1}, 9 \mu \mathrm{g} \mathrm{mL}^{-1}, 12 \mu \mathrm{g} \mathrm{mL}^{-1}, 15 \mu \mathrm{g} \mathrm{mL}^{-1}\right.$ ) based on the MTT assay (mean $\pm \mathrm{SD}, n=6$ ). A two-way ANOVA followed by the Student's $t$-test, ${ }^{* * P} \leq 0.01,{ }^{* * * P} \leq 0.001$ as compared with the PEI $1800 \mathrm{Da} / \mathrm{pZNF580}$ complex group. \#P $\leq 0.05$, \#\# $\leq 0.01$, and \#\#\#P $\leq$ 0.001 as compared with the NP/pZNF580 complex group.

induced by the PEI 1800 Da/pZNF580 and PEI 25 kDa/pZNF580 complexes was basically invariant. While the relative cell viability in the REDV-NP/pZNF580 complex group was much higher than that of NP/pZNF580 complex group at a concentration between 3-12 $\mu \mathrm{g} \mathrm{mL}{ }^{-1}$, and their relative cell viability was basically the same when the concentration was up to $15 \mu \mathrm{g} \mathrm{mL}{ }^{-1}$. In particularly, the relative cell viability in the REDV-NP/pZNF580 complex group was more than $100 \%$ at a concentration range of $3-12 \mu \mathrm{g} \mathrm{mL} \mathrm{m}^{-1}$, indicating their good cyto-compatibility.

\section{In vitro transfection of EA.hy926 cells}

pZNF580 plasmid is encoded with a GFP factor, so it is not only an objective gene, but also a report gene. Thus we used the green-fluorescence analysis to evaluate the transfection efficiency of ECs mediated by gene complexes. The plasmid expression results demonstrated that the fluorescence intensity increased with transfection time (Fig. S2, ESI $\dagger$ ). So the transfection efficiency of EA.hy926 cells mediated by different complexes was evaluated after incubation of $24 \mathrm{~h}$. Fig. 11 shows the epifluorescence (0) and bright field (1) images of EA.hy926 cells without any treatment and treated by different complexes at the $\mathrm{N} / \mathrm{P}$ molar ratio of 10 . The fluorescence intensity in the PEI 25 $\mathrm{kDa}$ /pZNF580 complex group (Fig. 11C) was much stronger than that in the PEI $1800 \mathrm{Da} /$ ZZNF580 group (Fig. 11B) due to its higher transfection efficiency. But the cell morphology changed and the total number of cells decreased after being transfected by the PEI $25 \mathrm{kDa}$ /pZNF580 complexes (Fig. 11C-1). This may be ascribed to the significant cytotoxicity of the PEI $25 \mathrm{kDa}$ complexes. Fig. 11D and E show that the GFP expressed by the NP/pZNF580 and REDV-NP/pZNF580 complexes, respectively. The fluorescence intensity in the REDV-NP/pZNF580 


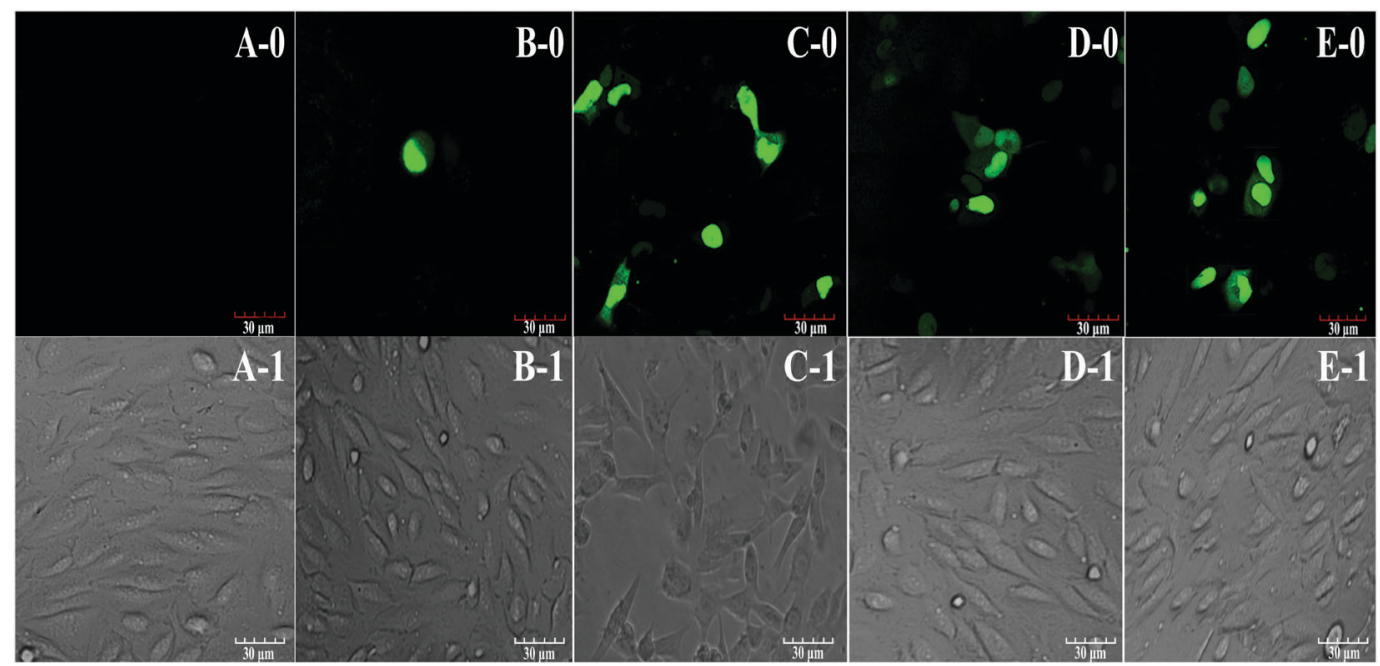

Fig. 11 The epifluorescence (0) and bright field (1) images of EA.hy926 cells without any treatment (A) and treated by PEI 1800 Da/pZNF580 complexes (B), PEI 25 kDa/pZNF580 complexes (C), NP/pZNF580 complexes (D) and REDV-NP/pZNF580 complexes (E) at a N/P molar ratio of 10 for incubating $24 \mathrm{~h}$.

complex group was higher than that in the NP/pZNF580 complex group, even a little higher than that in the PEI $25 \mathrm{kDa} / \mathrm{pZNF580}$ complex group. Additionally, the introduction of NP/pZNF580 and REDV-NP/pZNF580 complexes did not have much effect on the morphology and number of cells (Fig. 11D-1 and E-1). Because of the self-assembling strategy, several PEI 1800 Da chains were located at the surface of NPs and REDV-NPs, thus the high positive charge content endowed the NP/pZNF580 and REDV-NP/pZNF580 complex groups with much higher transfection efficiency than that of PEI $1800 \mathrm{Da} /$ pZNF580 complex group. In particularly, the pZNF580 plasmid was efficiently and significantly expressed in ECs by the REDV-NP carrier compared with other gene carriers, which may be attributed to the EC-specific peptide REDV.

Western blot analysis was used to characterize the pZNF580 protein level transfected by different polycationic carriers quantitatively, which can act as corroborative evidence for the transfection efficiency of EA.hy926 cells mediated by the gene complexes. As shown in Fig. 12, the relative pZNF580 protein transfected by REDV-NP/pZNF580 complexes was higher than that transfected by PEI $25 \mathrm{kDa} /$ pZNF580 complexes, NP/pZNF580 complexes and PEI $1800 \mathrm{Da} /$ pZNF580 complexes. These results were accordant with the transfection results obtained by fluorescence images, which indicated that REDV-NP can be a good carrier for PZNF580 delivery in ECs, and can be used potentially in gene therapy of cardiovascular diseases.

\section{Cell migration}

In response to wounding, cells migrate to the denuded area in a manner that mimics the pattern of cell migration in vivo. ${ }^{50}$ To examine whether the migration activity of ECs can be enhanced after being transfected by REDV-NP/pZNF580 complexes, scratch wound assay was operated on EA.hy926 cells, and the migration process at different time points treated by different complexes was shown in Fig. 13. It can be easily found that

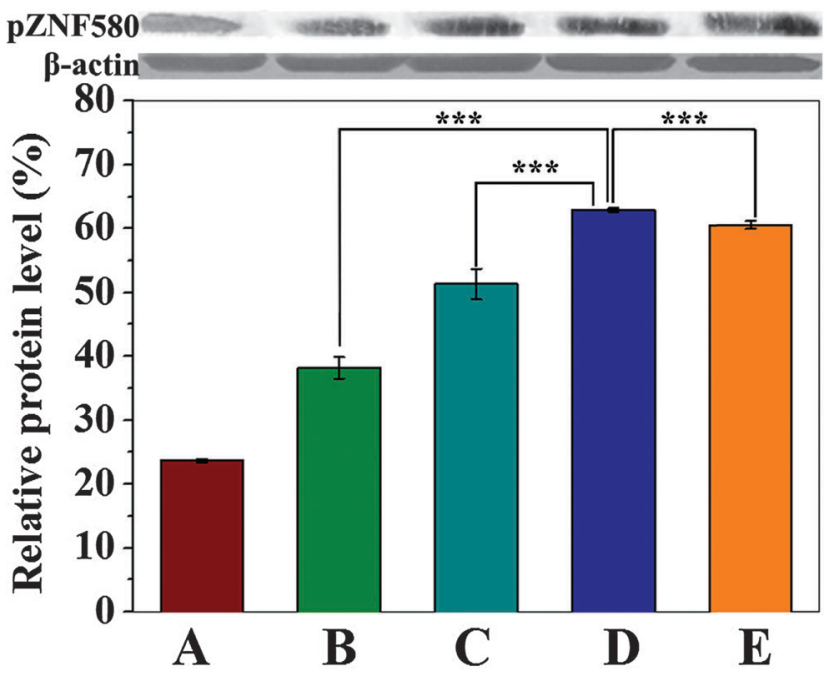

Fig. 12 Western blot analysis for pZNF580 protein expression in EA.hy926 cells: the model group without any treatment (A), PEI $1800 \mathrm{Da} / \mathrm{pZNF580}$ complex group (B), NP/pZNF580 complex group (C), REDV-NP/pZNF580 complex group (D) and PEI $25 \mathrm{kDa} / \mathrm{pZNF580} \mathrm{complex} \mathrm{group} \mathrm{(E)} \mathrm{at} \mathrm{the} \mathrm{N/P}$ molar ratio of 10 for $24 \mathrm{~h}$. (mean $\pm \mathrm{SD}, n=6,{ }^{* *} P \leq 0.001$ ).

untreated ECs hardly migrated into the denuded area after $12 \mathrm{~h}$, while ECs treated with PEI 1800 Da/pZNF580, NP/pZNF580, REDV$\mathrm{NP} /$ pZNF580 and PEI $25 \mathrm{kDa} /$ pZNF580 complexes increased the migration area by different degrees. It is worthy to note that the cell number in PEI $25 \mathrm{kDa} /$ pZNF580 complex group reduced partially owing to the significant cytotoxicity of the PEI $25 \mathrm{kDa}$ carrier. The migration ability of ECs mediated by different complexes was quantitatively evaluated by the relative recovered surface area. As shown in Fig. 14, the relative recovered surface area of ECs was up to $(91.5 \pm 3.0) \%$ in the REDV-NP/pZNF580 complex group, while $(86.2 \pm 2.6) \%$ in the PEI $25 \mathrm{kDa} / \mathrm{pZNF} 580$ complex group, $(71.8 \pm 4.6) \%$ in the NP/pZNF580 complex group, $(56.8 \pm 4.8) \%$ in the PEI $1800 \mathrm{Da} /$ pZNF580 complex group 


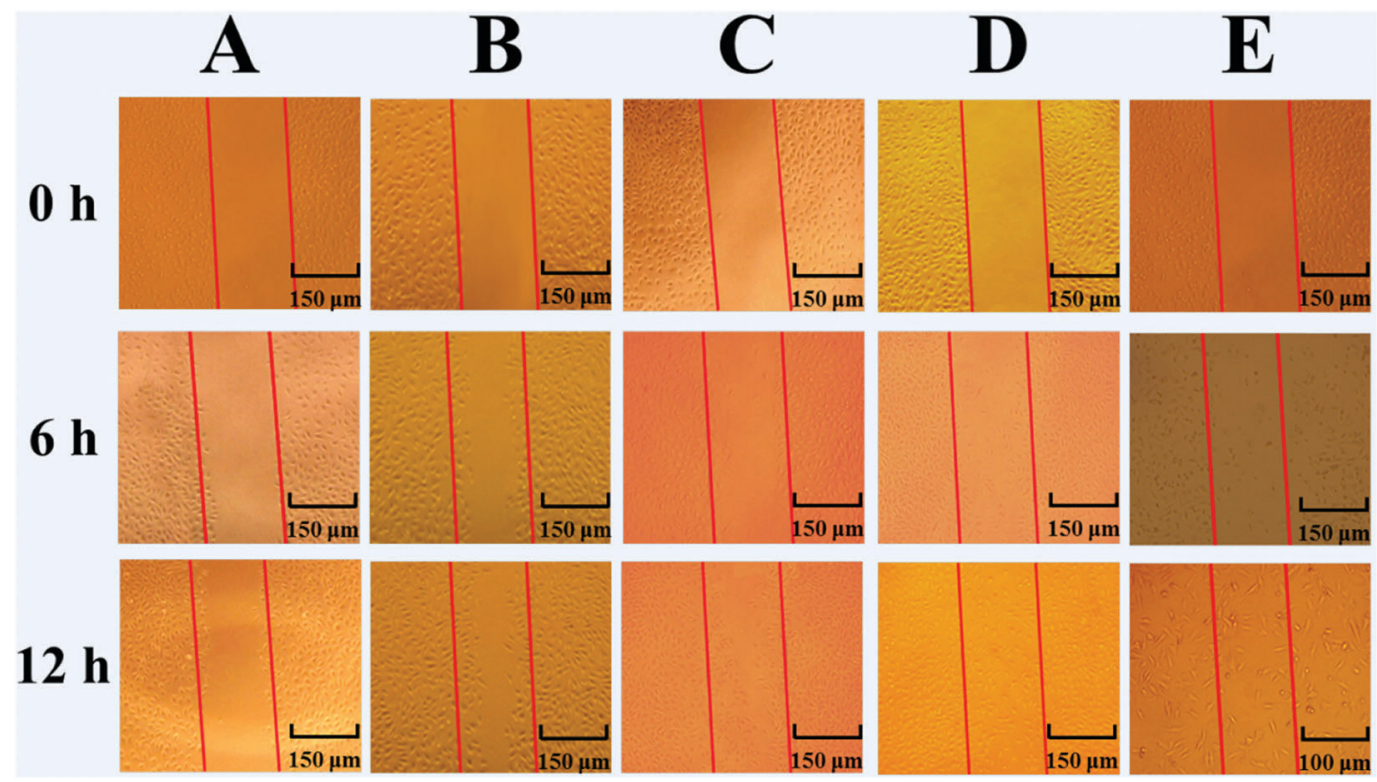

Fig. 13 Migration processes of EA.hy926 cells in the blank control group (A), PEl 1800 Da/pZNF580 complex group (B), NP/pZNF580 complex group (C), REDV-NP/pZNF580 complex group (D) and PEl $25 \mathrm{kDa} / \mathrm{pZNF580} \mathrm{complex} \mathrm{group} \mathrm{(E)} \mathrm{(N/P} \mathrm{=} \mathrm{10)} \mathrm{at} \mathrm{0,} \mathrm{6,} \mathrm{and} 12 \mathrm{~h}$.

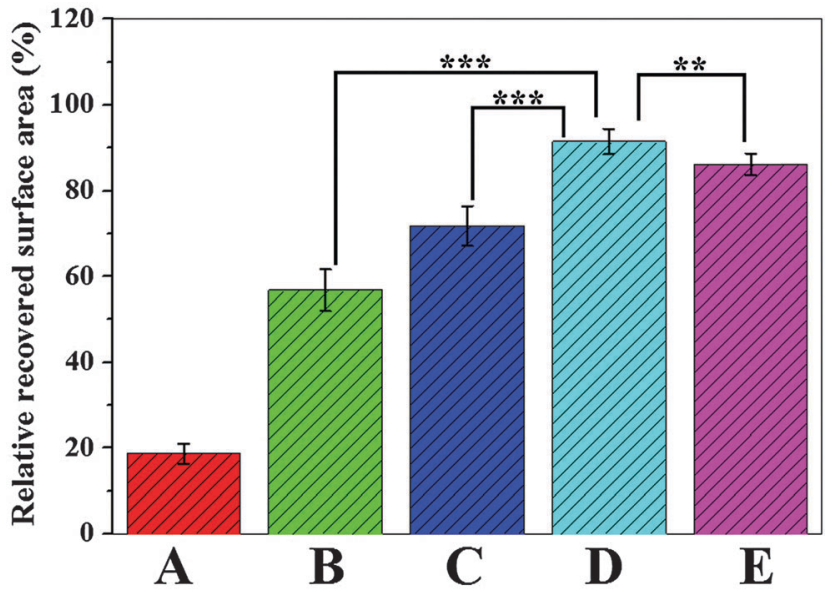

Fig. 14 Relative recovered surface area (\%) in the blank control group (A), PEI 1800 Da/pZNF580 complex group (B), NP/pZNF580 complex group (C), REDV-NP/pZNF580 complex group (D) and PEI $25 \mathrm{kDa} / \mathrm{pZNF580}$ complex group (E) at a N/P molar ratio of 10 after $12 \mathrm{~h}$ calculated by "Image J" software (mean $\pm \mathrm{SD}, n=6,{ }^{* \star} P \leq 0.01,{ }^{* \star *} P \leq 0.001$ ).

and $(18.7 \pm 2.4) \%$ in the control group. These results revealed that REDV-NP/pZNF580 complexes can surely promote the migration of ECs. It may be due to the specific recognition of the REDV peptide to the integrin of ECs, and the corresponding protein transfected by the pZNF580 can up-regulate the migration capability of ECs, which is consistent with previous reports. ${ }^{20,21}$

\section{Discussion}

Rapid and complete endothelialization has been recognized as an effective method for avoiding a series of pathological processes caused by using small caliber prosthetic vascular grafts in intervention therapy. Gene engineering and specific peptidemediated therapies are effective strategies for promoting endothelialization. Thus, the investigation on the combination of gene engineering and bioactive peptides to promote the transfection efficiency of ECs is very significant.

In this paper, we synthesized a targeting polycationic gene delivery carrier modified with the REDV peptide. The targeting polycationic gene carrier was prepared by ROP and graft reaction. Firstly, mPEG-P(LA-co-CL) was synthesized by ROP of LA and CL using mPEG as an initiator. Secondly, low molecular weight PEI was grafted onto the succinylated mPEG-P(LA-Co-CL) to obtain mPEG-P(LA-co-CL)-PEI amphiphilic block copolymers. Finally, the targeting gene delivery carrier was prepared by the modification of mPEG-P(LA-co-CL)-PEI with the CREDVW peptide via a bifunctional linker OPSS-PEG-NHS.

A self-assembling method was used to prepare targeting REDV-NPs and non-targeting NPs. We utilized gel retardation assay to investigate the compressing plasmid capability of REDV-NP and NP carriers. It can be found that the N/P molar ratio played an important role in controlling the electrophoretic mobility of the pZNF580 plasmid in gene complexes. NP and REDV-NP carriers could completely compress the pZNF580 plasmid into stable complexes when the N/P molar ratios were 5 and 10 , respectively. The difference may be attributed to the introduction of the CREDVW peptide. The reaction of the OPSS-PEG-NHS linker and PEI chains would reduce the amino groups of the copolymer, and the increased PEG content by OPSS-PEG-NHS would also shield the positive charge of the REDV-NPs. So a higher N/P value was needed for REDV-NPs to condense the pZNF580 plasmid completely. Thus, the N/P molar ratio of 10 was selected in the following studies in order to obtain stable NP/pZNF580 and REDV-NP/pZNF580 complexes. The results confirmed that both of them can protect pZNF580 against DNase I degradation at an N/P molar ratio of 10. 
The relative cell viability results by the MTT assay indicated that both NP/pZNF580 and REDV-NP/pZNF580 complexes exhibited lower cytotoxicity than PEI 1800 Da/pZNF580 and PEI $25 \mathrm{kDa} / \mathrm{pZNF} 580$ complexes, and the cytotoxicity of REDV-NP/ pZNF580 complexes was much lower at the plasmid concentration

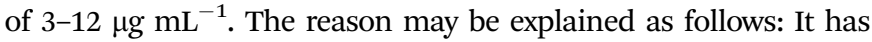
been proved that the cytotoxicity of polycations is usually due to the large accumulation of cationic polymers on the negatively charged cell membrane surface via the strong electrostatic interaction. ${ }^{51}$ The poly(ethylene glycol) spacer can cushion the adsorption of the polymer towards the cell membrane in some degree. ${ }^{52}$ The low cytotoxicity of NP/pZNF580 and REDV-NP/pZNF580 complexes may be related to their mPEG chains. Owing to the linker of OPSS-PEG-NHS, the distribution of poly(ethylene glycol) chains on the surface of REDV-NPs is higher than that of NPs, so REDV-NP/ pZNF580 complexes have better cyto-compatibility than other complexes.

The transfection efficiency of mediated ECs by REDV-NP complexes was higher than that by NP complexes, even slightly better than the PEI $25 \mathrm{kDa}$ carrier, which may be ascribed to targeting the REDV peptide. Because transfection efficiency is usually associated with the size and zeta potential of carriers, ${ }^{53}$ appropriate size and high zeta potential value could facilitate cell uptake. The PEI $25 \mathrm{kDa}$ carrier showing high transfection efficiency benefits from its high zeta potential, ${ }^{53}$ while REDVNPs had a relatively low zeta potential compared to PEI $25 \mathrm{kDa}$. Thus the transfection efficiency of REDV-NP complexes should be enhanced by targeting the REDV peptide. This can also be proved by significant difference of the transfection efficiency between NP and REDV-NP complex groups, but they had almost similar size and zeta potential. The REDV-NPs can increase the recognition to ECs owing to the specific selectivity between the REDV peptide and the $\alpha 4 \beta 1$ integrin of ECs. REDV-NP/pZNF580 complexes were efficiently and selectively adsorbed onto the surface of the ECs, which benefited the complexes to enter in cells by endocytosis. In order to elucidate the specific recognition process of the REDV peptide functionalized polycationic gene carrier, we further co-cultured ECs and SMCs $1: 1$ in cell number) with gene complexes. During the co-culture, ECs specifically adhered and uptook REDV-NP complexes, subsequently proliferated quickly in $24 \mathrm{~h}$, while SMCs proliferated slowly as demonstrated by fluorescence analysis (Fig. S3, ESI $\dagger$ ).

After internalization of the targeting complexes, the cytoplasm trafficking takes place to initiate plasmid transcription and translation. ${ }^{38,45}$ Thus pZNF580 plasmids were expressed well in ECs delivered by a REDV-NP carrier. The results demonstrated that the combination of the gene delivery carrier and targeting peptide modification could promote pZNF580 gene transfection in human ECs.

Western blot analysis indicated that the pZNF580 protein level expressed by REDV-NP/pZNF580 complexes in ECs was higher than that expressed by NP/pZNF580 and PEI $25 \mathrm{kDa} /$ pZNF580 complexes. The consistent results of transfection and protein assay experiments confirmed the high transfection efficiency of mediated ECs by targeting peptide functionalized gene carriers. Additionally, the introduction of the REDV peptide into the polycationic gene carrier could also promote the migration capability of ECs proved from the scratch wound assay, which benefited for revascularization.

One important future research direction would be the optimization of the ratio of the REDV peptide and the polycationic gene carrier. Besides the investigation on the proliferation and migration of ECs transfected by the targeting gene-complexes, we will study the competitive biological activity of ECs and SMCs affected by these targeting gene complexes in detail.

\section{Conclusion}

In this study, REDV-mediated polycationic nanoparticles have been used as a targeting gene carrier for pEGFP-ZNF580 plasmid transfection in endothelial cells. We have found that the complexes of pEGFP-ZNF580 and the targeting REDV nanoparticle efficiently promoted the transfection and migration of endothelial cells owing to the specific selectivity of REDV to endothelial cells and the high positive charge of the carrier. We believe that the strategy for constructing a targeting peptide functionalized polycationic gene system may be a promising platform for enhancing the endothelialization of artificial vascular grafts, and can be potentially applied in the interventional therapy of cardiovascular diseases in future.

\section{Acknowledgements}

This work is supported by the National Nature Science Foundation of China (No. 31370969), PhD Programs Foundation of Ministry of Education of China (No. 20120032110073), International Cooperation from Ministry of Science and Technology of China (No. 2013DFG52040), and the Program of Introducing Talents of Discipline to Universities of China (No. B06006).

\section{References}

1 T. Asakura, M. Isozaki, T. Saotome, K. I. Tatematsu, H. Sezutsu, N. Kuwabara and Y. Nakazawa, J. Mater. Chem. B, 2014, 2, 7375-7383.

2 K. N. Kader, J. M. Sweany and R. V. Bellamkonda, J. Biomed. Mater. Res., 2002, 60, 405-410.

3 X. L. Liu, L. Yuan, D. Li, Z. C. Tang, Y. W. Wang, G. J. Chen, H. Chen and J. L. Brash, J. Mater. Chem. B, 2014, 2, 5718-5738.

4 G. Acharya and K. Park, Adv. Drug Delivery Rev., 2006, 58, 387-401.

5 Y. Wei, Y. Ji, L. Xiao, Q. Lin and J. Ji, Colloids Surf., B, 2011, 84, 369-378.

6 L. Zhang and Y. K. Feng, Curr. Sci., 2014, 106, 816-822.

7 J. Yang, J. Lv, M. Behl, A. Lendlein, D. Yang, L. Zhang, C. Shi, J. Guo and Y. Feng, Macromol. Biosci., 2013, 13, 1681-1688.

8 B. Gao, Y. Feng, J. Lu, L. Zhang, M. Zhao, C. Shi, M. Khan and J. Guo, Mater. Sci. Eng., C, 2013, 33, 2871-2878.

9 J. Yang, J. Lv, B. Gao, L. Zhang, D. Yang, C. Shi, J. Guo, W. Li and Y. Feng, Front. Chem. Sci. Eng., 2014, 8, 188-196. 
10 W. Yuan, Y. Feng, H. Wang, D. Yang, B. An, W. Zhang, M. Khan and J. Guo, Mater. Sci. Eng., C, 2013, 33, 3644-3651.

11 H. Wang, Y. Feng, Z. Fang, W. Yuan and M. Khan, Mater. Sci. Eng., C, 2012, 32, 2306-2315.

12 C. Shi, W. Yuan, M. Khan, Q. Li, Y. Feng, F. Yao and W. Zhang, Mater. Sci. Eng., C, 2015, 50, 201-209.

13 M. Khan, J. Yang, C. Shi, Y. Feng, W. Zhang, K. Gibney and G. N. Tew, RSC Adv., 2015, 5, 11284-11292.

14 W. Zhou, Y. Feng, J. Yang, J. Fan, J. Lv, L. Zhang, J. Guo, X. Ren and W. Zhang, J. Mater. Sci.: Mater. Med., 2015, 26, 1-14.

15 M. Khan, J. Yang, C. C. Shi, Y. K. Feng, W. C. Zhang, K. Gibney and G. N. Tew, Macromol. Mater. Eng., 2015, DOI: $10.1002 /$ mame.201500038.

16 T. Liu, S. Liu, K. Zhang, J. Chen and N. Huang, J. Biomed. Mater. Res., Part A, 2014, 102, 3754-3772.

17 A. Kawamoto, T. Asahara and D. W. Losordo, Cardiovasc. Radiat. Med., 2002, 3, 221-225.

18 B. Kealy, A. Liew, J. M. McMahon, T. Ritter, A. O'Doherty, M. Hoare, U. Greiser, E. E. Vaughan, M. Maenz, C. O'Shea, F. Barry and T. O'Brien, Tissue Eng., Part C, 2009, 15, 223-231.

19 H. Y. Nam, K. Nam, H. J. Hahn, B. H. Kim, H. J. Lim, H. J. Kim, J. S. Choi and J. S. Park, Biomaterials, 2009, 30, 665-673.

20 W. C. Zhang, S. P. Wei, H. Y. Sun, B. Hou and W. L. Hu, Acta Academiae Mediciane CPAF, 2011, 20, 605-608.

21 Y. Luo, Y. Zhao, X. Li, J. Zhao and W. Zhang, Mol. Cell. Biochem., 2014, 393, 199-207.

22 D. L. Ren, H. K. Wang, J. Q. Liu, M. H. Zhang and W. C. Zhang, Mol. Cell. Biochem., 2012, 359, 183-191.

23 H. Y. Sun, S. P. Wei, R. C. Xu, P. X. Xu and W. C. Zhang, Biochem. Biophys. Res. Commun., 2010, 395, 361-366.

24 Y. N. Yue and C. Wu, Biomater. Sci., 2013, 1, 152-170.

25 M. A. Gosselin, W. J. Guo and R. J. Lee, Bioconjugate Chem., 2001, 12, 989-994.

26 Y. Negishi, Y. Tsunoda, N. Hamano, D. Omata, Y. EndoTakahashi, R. Suzuki, K. Maruyama, M. Nomizu and Y. Aramaki, Biopolymers, 2013, 100, 402-407.

27 M. Turk, S. Dincer, I. G. Yulug and E. Piskin, J. Controlled Release, 2004, 96, 325-340.

28 T. Hudde, S. A. Rayner, R. M. Comer, M. Weber, J. D. Isaacs, H. Waldmann, D. F. Larkin and A. J. George, Gene Ther., 1999, 6, 939-943.

29 S. C. McBain, H. H. P. Yiu, A. El Haj and J. Dobson, J. Mater. Chem., 2007, 17, 2561-2565.

30 L. Zhang, C. H. Hu, S. X. Cheng and R. X. Zhuo, Colloids Surf., B, 2010, 76, 427-433.
31 C. Yang, H. Li, S. H. Goh and J. Li, Biomaterials, 2007, 28, 3245-3254.

32 X. Zhao, Z. Li, H. Pan, W. Liu, M. Lv, F. Leung and W. W. Lu, Acta Biomater., 2013, 9, 6694-6703.

33 X. Shuai, T. Merdan, F. Unger and T. Kissel, Bioconjugate Chem., 2005, 16, 322-329.

34 C. C. Shi, F. L. Yao, J. W. Huang, G. L. Han, Q. Li, M. Khan, Y. K. Feng and W. C. Zhang, J. Mater. Chem. B, 2014, 2, 1825-1837.

35 C. Shi, F. Yao, Q. Li, M. Khan, X. Ren, Y. Feng, J. Huang and W. Zhang, Biomaterials, 2014, 35, 7133-7145.

36 J. Lv, X. Hao, J. Yang, Y. Feng, M. Behl and A. Lendlein, Macromol. Chem. Phys., 2014, 215, 2463-2472.

37 Q. Li, C. Shi, W. Zhang, M. Behl, A. Lendlein and Y. Feng, Adv. Healthcare Mater., 2015, DOI: 10.1002/adhm.201400817.

38 G. Kibria, H. Hatakeyama, N. Ohga, K. Hida and H. Harashima, J. Controlled Release, 2011, 153, 141-148.

39 J. A. Hubbell, S. P. Massia, N. P. Desai and P. D. Drumheller, Biotechnology, 1991, 9, 568-572.

40 Q. K. Lin, Y. Hou, K. F. Ren and J. Ji, Thin Solid Films, 2012, 520, 4971-4978.

41 Y. Liu, T. T. Yang Tan, S. Yuan and C. Choong, J. Mater. Chem. B, 2013, 1, 157.

42 F. C. Tanner, D. P. Carr, G. J. Nabel and E. G. Nabel, Cardiovasc. Res., 1997, 35, 522-528.

43 H. Dannowski, J. Bednarz, R. Reszka, K. Engelmann and U. Pleyer, Exp. Eye Res., 2005, 80, 93-101.

44 U. Pleyer, D. Groth, B. Hinz, O. Keil, E. Bertelmann, P. Rieck and R. Reszka, Exp. Eye Res., 2001, 73, 1-7.

45 C. W. Chen, M. K. Yeh, C. Y. Shiau, C. H. Chiang and D. W. Lu, Int. J. Nanomed., 2013, 8, 2613-2627.

46 Z. Shan, Y. Tan, L. Qin, G. Li, X. Pan, Z. Wang, X. Yu, Q. Wang and C. Wu, Int. J. Pharm., 2014, 466, 390-399.

47 D. Nuvoli, V. Alzari, R. Sanna, S. Scognamillo, M. Piccinini, L. Peponi, J. M. Kenny and A. Mariani, Nanoscale Res. Lett., 2012, 7, 674 .

48 N. Zuidam, G. Posthumab, E. de Vries, D. Crommelin, W. Hennink and G. Storm, J. Drug Targeting, 2000, 8, 51-66.

49 K. A. Mislick and J. D. Baldeschwieler, Proc. Natl. Acad. Sci. U. S. A., 1996, 93, 12349-12354.

50 P. Liang, B. Jiang, C. Lv, X. Huang, L. Sun, P. Zhang and X. Huang, Biochim. Biophys. Acta, 2013, 1830, 4500-4512.

51 T. Merdan, J. Kopecek and T. Kissel, Adv. Drug Delivery Rev., 2002, 54, 715-758.

52 P. Calvo, B. Gouritin, H. Chacun, D. Desmaele, J. D’Angelo, J. P. Noel, D. Georgin, E. Fattal, J. P. Andreux and P. Couvreur, Pharm. Res., 2001, 18, 1157-1166.

53 K. Kunath, A. von Harpe, D. Fischer, H. Peterson, U. Bickel, K. Voigt and T. Kissel, J. Controlled Release, 2003, 89, 113-125. 